\title{
Analisis Daya Dukung Lateral pada Suction Pile dengan Menggunakan Metode Numerik
}

\author{
R. THASYIA PUTERI DEARINI J., INDRA NOER HAMDHAN \\ Jurusan Teknik Sipil, Institut Teknologi Nasional, Bandung \\ Email: puteri626@gmail.com
}

\begin{abstract}
ABSTRAK
Suction Pile merupakan fondasi berbentuk silinder baja berdiameter besar yang tertutup pada bagian atas dan terbuka pada bagian bawah. Fondasi ini sering digunakan untuk menyokong bangunan offshore dan platforms. Beban yang diterima oleh suction pile merupakan beban aksial yang berasal dari beban strukturnya dan juga beban lateral dari tekanan tanah dan air laut di sekelilingnya. Analisis daya dukung lateral pada suction pile dilakukan dengan menggunakan metode numerik, yaitu menggunakan software PLAXIS 3D dengan soil model Mohr-Coulomb dan Hardening Soil, serta menggunakan metode analisis, yaitu metode COM624 dari Federal Highway Administrasion (FHWA). Pemodelan suction pile dilakukan dengan cara memvariasikan panjang dari suction pile dengan mutu baja, diameter suction pile, dan parameter tanah yang sama. Berdasarkan hasil dari penelitian bahwa semakin panjang penampang dari suction pile yang digunakan, maka daya dukung lateral yang diperoleh semakin meningkat dikarenakan letak titik jepit yang masih berubah.
\end{abstract}

Kata Kunci: suction pile, daya dukung lateral, titik jepit, Mohr-Coulomb, Hardening Soil

\begin{abstract}
Suction pile is a large cylinder-shaped steel foundation which has a closed top and an open bottom. This foundation is often used to support offshore buildings and platforms. The loads resisted by the suction pile are the axial load from its own structure weight and the lateral load caused by soil and deep-sea pressure around it. Analysis of lateral bearing capacity of suction pile is done by using numerical method is conducted using commercial software PLAXIS 3D, with Mohr-Coulomb and Hardening Soil as the soil model and analysis method is conducted using COM624 method from Federal Highway Administrasion (FHWA). Suction pile model is designed by varying the suction pile lengths of equal steel quality, suction pile diameter, and soil parameter. The result of the research showed that the longer the cross section of the suction pile used, the higher its lateral bearing capacity, due to the location of the fixity point is still changed.
\end{abstract}

Keywords: suction pile, lateral bearing capacity, fixity point, Mohr-Coulomb, Hardening Soil 


\section{PENDAhUluan}

Dalam kegiatan eksplorasi minyak bumi dan gas alam, dibutuhkan struktur yang dibangun di lepas pantai untuk menunjang kegiatan tersebut. Fondasi yang digunakan untuk bangunan yang berada di lepas pantai ini salah satunya menggunakan Suction Pile. Suction Pile merupakan fondasi berbentuk silinder baja berdiameter besar yang tertutup pada bagian atas dan terbuka pada bagian bawah. Beban aksial yang diterima oleh suction pile berasal dari beban struktur diatasnya sedangkan beban lateral yang ditahannya berasal dari tekanan tanah dan air laut disekelilingnya. Pada perencanaan suction pile sendiri berbeda dengan fondasi lain dalam menerima beban, jenis tanah juga merupakan salah satu faktor terpenting akibat letaknya yang berada di lepas pantai membuat analisis daya dukung fondasi menjadi sedikit berbeda dengan fondasi pada umumnya.

Pada tugas akhir ini akan menganalisis daya dukung suction pile dalam menahan beban beban lateral menggunakan PLAXIS 3D sebagai metode pendekatan secara numerik berdasarkan defleksi lateral yang diizinkan.

Penelitian ini bertujuan untuk menganalisis berapa besar daya dukung ultimate lateral pada suction pile dengan metode pendekatan secara numerik dan analisis manual, kemudian menerapkan variasi yang berbeda pada panjang suction pile, serta untuk mengetahui berapa besar pengaruh kondisi tersebut terhadap daya dukung ultimate lateral.

\section{TINJAUAN PUSTAKA}

\subsection{Suction Pile}

Suction Pile adalah salah satu jenis fondasi dalam. Fondasi ini banyak digunakan untuk menahan dan menyalurkan beban struktur atas ke dasar laut. Suction pile sendiri berbentuk silinder yang terbuka pada bagian dasarnya dan tertutup pada bagian atasnya, dengan lubang udara pada bagian atasnya (Allersma et al, 1999).

Proses Instalasi Suction Pile dibagi menjadi 2 (dua), yaitu:

1. Self-weight penetrasion phase

Pada tahap ini suction pile diletakan pada lokasi yang telah ditentukan. Suction pile akan turun secara pelahan akibat berat sendiri dan celah udara (vent) yang terdapat pada bagian atas dibiarkan terbuka.

\section{Suction-assisted penetrasion phase}

Pada tahapan ini, pompa digunakan untuk mengalirkan air yang terdapat di dalam suction pile dan menutup celah udara (vent). Proses keluarnya air ini berfungsi untuk menurunkan tekanan di dalam pile, sehingga mendorong suction pile untuk turun dan masuk ke dalam dasar laut (Houlsby et al, 2005)

\subsection{Beban Lateral}

Beban lateral merupakan beban yang arah geraknya secara horizontal. Beban lateral ini dapat menyebabkan suatu fondasi mengalami deformasi atau defleksi yang dapat memberikan dampak buruk pada suatu struktur.

Defleksi desain dalam arah lateral berdasarkan SNI (2017), defleksi lateral yang diizinkan pada fondasi bergantung kepada kategori struktur dan resiko gempa struktur atasnya. Pada umumnya defleksi lateral yang diizinkan pada fondasi tidak lebih dari $2,50 \mathrm{~cm}$ atau sama dengan 1 inch. 


\subsection{Daya Dukung Lateral Metode COM624}

Metode analisis COM624 dari Federal Highway Administrasion (FHWA, 1991) merupakan metode analisis daya dukung lateral yang menggunakan pendekatan reaksi subgrade berdasarkan defleksi lateral. COM624 menggunakan Persamaan 1 differential nonlinear untuk analisis beban lateral, berikut persamaan dari COM624:

$$
E I \frac{d^{4} . Y}{d Z^{4}}+Q \frac{d^{2} Y}{d Z^{2}}-R-P_{q}=0
$$

halmana:

$Q=$ beban aksial pada fondasi [kN],

$Y=$ defleksi lateral pada fondasi [m],

$Z=$ kedalaman dari atas fondasi $[\mathrm{m}]$,

$R=$ modulus reaksi subgrade $\left[\mathrm{MN} / \mathrm{m}^{3}\right]$,

$E=$ modulus elastisitas fondasi $\left[\mathrm{kN} / \mathrm{m}^{2}\right]$,

$I=$ momen inersia fondasi $\left[\mathrm{m}^{4}\right]$,

$P_{q}=$ distribusi beban sepanjang fondasi $[\mathrm{kN}]$.

\subsection{PLAXIS 3D}

PLAXIS 3D adalah salah satu program PLAXIS yang mampu menampilkan bentuk deformasi, stabilitas tanah, penurunan, dan berbagai perilaku tanah saat diberi beban. PLAXIS 3D dapat menampilkan tampilan grafis yang nyaman untuk digunakan oleh pengguna sehingga dengan cepat mampu membuat geometri model dan membuat ukuran elemen hingga.

\subsection{Keruntuhan Mohr-Coulomb}

Keruntuhan Mohr-Coulomb adalah teori keruntuhan yang menyatakan bahwa keruntuhan pada suatu material akibat kombinasi kritis antara tegangan normal dan geser (Mohr, 1900). Hubungan antara tegangan normal dan geser pada sebuah bidang keruntuhan dapat dinyatakan dalam Persamaan 2 berikut.

$$
\tau=c+\sigma(\tan \varphi)
$$

halmana:

$\tau=$ kuat geser tanah $\left[\mathrm{kN} / \mathrm{m}^{2}\right]$,

$c=$ kohesi tanah $\left[\mathrm{kN} / \mathrm{m}^{2}\right]$,

$\varphi=$ sudut geser tanah $\left[{ }^{\circ}\right]$,

$\sigma=$ tegangan normal pada bidang runtuh $\left[\mathrm{kN} / \mathrm{m}^{2}\right]$.

\subsection{Keruntuhan Hardening Soil}

Hardening soil model adalah jenis keruntuhan geser tanah pada model tingkat lanjutan untuk memodelkan berbagai jenis perilaku tanah lunak maupun tanah keras (Schanz, 1998). Perbedaan antara model Hardening Soil dan model Mohr-Coulomb terletak pada hubungan nilai tegangan dan regangan. Pada Mohr-Coulomb dijelaskan bahwa pembatasan nilai tegangan berdasarkan nilai sudut geser sedangkan pada Hardening Soil mode/ menjelaskan jenis elastoplastis dari model hiperbolik dimana hubungan tegangan dan regangan ini dikembangkan untuk deformasi tanah. Pada hardening soil mode/ parameter kekakuan tanah dijelaskan jauh lebih akurat dibandingkan dengan Mohr-Coulomb karena menggunakan 3 parameter kekakuan, yaitu triaxial stiffness $\left(E_{50}\right)$, triaxial unloading stiffness $\left(E_{u r}\right)$ dan oedometer loading stiffness $\left(E_{\text {oed }}\right)$. 


\section{METODE PENELITIAN}

Pemodelan suction pile yang dilakukan menggunakan program PLAXIS 3D. Pemodelan ini dilakukan dengan asumsi tanah pasir. Model divariasikan dengan cara mengubah panjang suction pile sehingga dianalisis untuk mengetahui besar pengaruh panjang suction pile terhadap daya dukung lateral berdasarkan batas defleksi lateral yang diijinkan. Bagan alir dari penelitian ini ditunjukan Gambar 1.

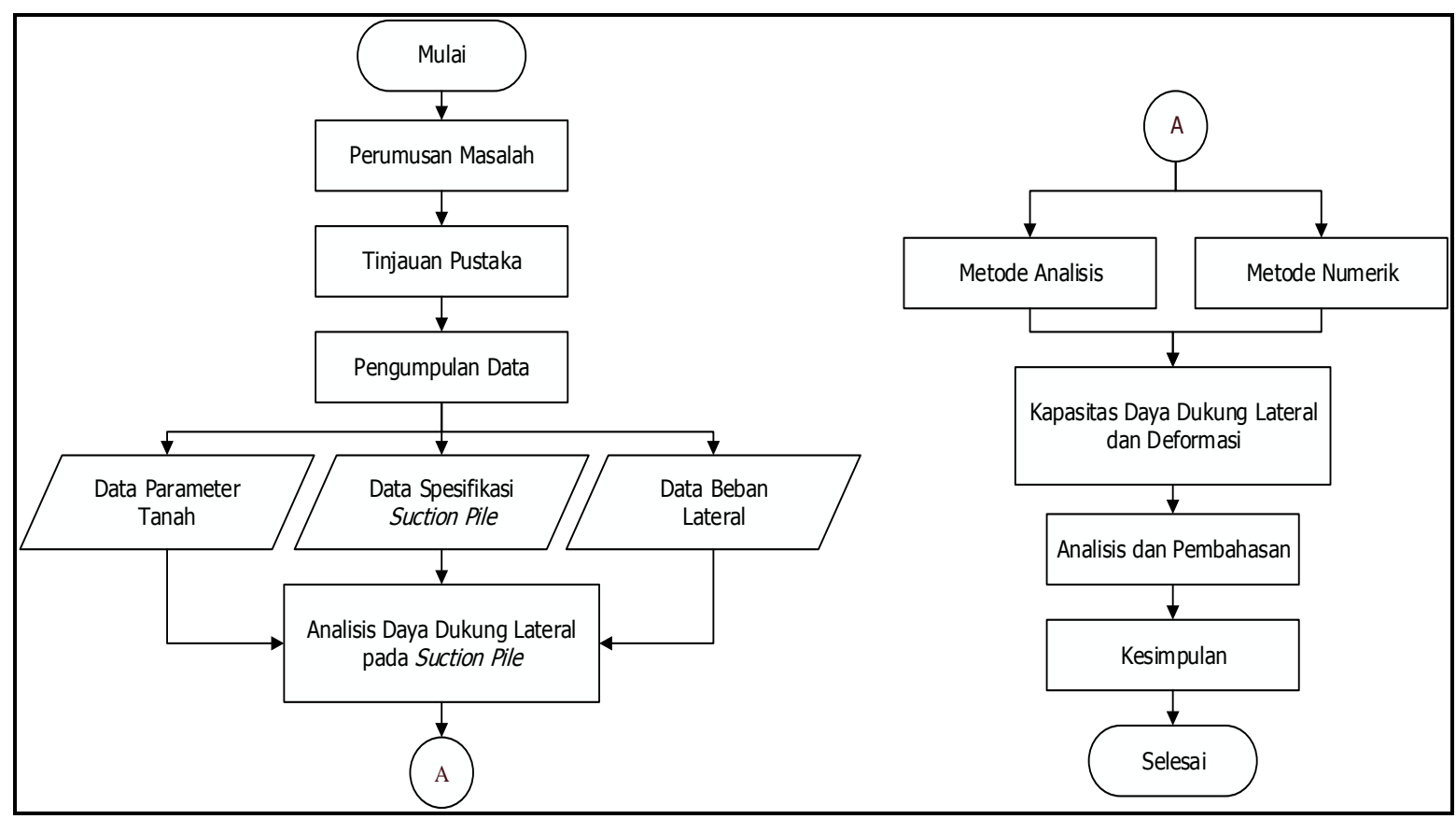

Gambar 1. Bagan alir analisis daya dukung lateral pada suction pile

\section{HASIL PENELITIAN DAN PEMBAHASAN}

\subsection{Daya Dukung Lateral Metode Numerik}

Analisis daya dukung lateral suction pile menggunakan program PLAXIS 3D, pemodelan dilakukan dengan memberikan muka air tanah yang berada di atas lapisan tanah dan suction pile setinggi 1 meter. Pemodelan muka air tanah ini menyerupai keadaan suction pile yang berada di dasar laut dan keadaan tanah pasir yang jenuh. Rasio panjang dan diameter atau variasi panjang suction pile yang digunakan adalah 3 meter (1:1), 6 meter (1:2), 9 meter (1:3), 12 meter (1:4), 15 meter (1:5), 18 meter (1:6), 21 meter (1:7), dan 24 meter (1:8) dengan kondisi kepala bebas (free head). Pemodelan dari struktur suction pile yang dianalisis dapat dilihat pada Gambar 2. Adapun data parameter tanah dan suction pile yang digunakan dalam menganalisis daya dukung lateral pada PLAXIS 3D dapat dilihat pada Tabel $\mathbf{1}$ dan Tabel 2. 


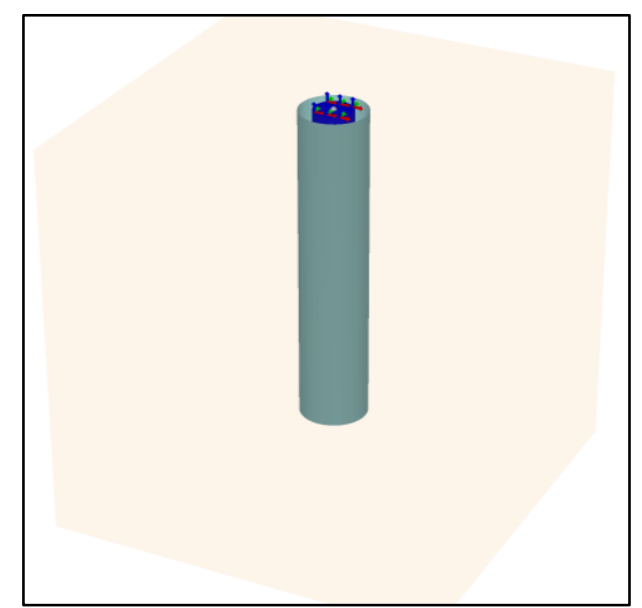

\section{Gambar 2. Pemodelan suction pile pada PLAXIS 3D}

Tabel 1. Parameter Tanah

\begin{tabular}{|c|c|c|c|c|c|c|c|c|c|c|}
\hline \multirow{3}{*}{ Model Tanah } & \multirow{3}{*}{ Jenis } & \multirow{2}{*}{$\gamma_{u n s a t}$} & \multirow{2}{*}{$\gamma_{s a t}$} & \multicolumn{3}{|c|}{$E$} & \multirow{3}{*}{$v$} & \multirow{3}{*}{$C$} & \multirow{2}{*}{$\phi$} & \multirow{2}{*}{$\varphi$} \\
\hline & & & & $E_{50}$ & $E_{\text {oed }}$ & $E_{u r}$ & & & & \\
\hline & & {$\left[\mathrm{kN} / \mathrm{m}^{3]}\right.$} & {$\left[\mathrm{kN} / \mathrm{m}^{3}\right]$} & & {$\left[\mathrm{kN} / \mathrm{m}^{2}\right]$} & & & & [0] & {$\left[{ }^{\circ}\right]$} \\
\hline Mohr-Coulomb & Drained & 16 & 17 & & 15.000 & & 0,33 & 0,1 & 35 & 5 \\
\hline Hardening Soil & Drained & 16 & 17 & 15.000 & 15.000 & 30.000 & 0,33 & 0,1 & 35 & 5 \\
\hline
\end{tabular}

Tabel 2. Parameter Suction Pile

\begin{tabular}{ccccc}
\hline Tebal Pelat & Berat Jenis & Modulus Elastisitas & Poisson Rasio & Modulus Geser \\
\hline $\boldsymbol{d}$ & $\gamma$ & $\boldsymbol{E}$ & $\checkmark$ & $\boldsymbol{G}$ \\
\hline$[\mathbf{m}]$ & {$\left[\mathbf{k N} / \mathbf{m}^{3}\right]$} & {$\left[\mathbf{k N} / \mathbf{m}^{2}\right]$} & - & {$\left[\mathbf{k N} / \mathbf{m}^{3}\right]$} \\
\hline 0,05 & 63,4 & $200 \times 10^{6}$ & 0,33 & $75,19 \times 10^{6}$ \\
\hline
\end{tabular}

Hasil analisis menggunakan metode numerik yaitu program PLAXIS 3D berupa variasi daya dukung lateral akibat dari pengaruh ukuran dimensi suction pile. Pada analisis ini, daya dukung lateral diperoleh berdasarkan batas defleksi lateral yang diizinkan yaitu sebesar $2,5 \mathrm{~cm}$. Saat suction pile memikul beban lateral, defleksi lateral akan terjadi di daerah permukaan yang mengikuti arah beban lateral yang diberikan seperti yang dapat dilihat pada Gambar 3.

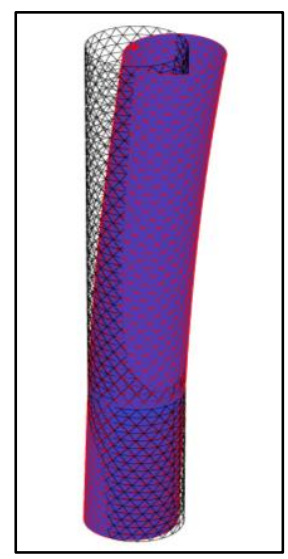

Gambar 3. Suction pile mengalami defleksi akibat beban lateral 


\section{A) Pemodelan dengan Model Mohr-Coulomb}

Pemodelan yang dilakukan pertama kali adalah pemodelan dengan menggunakan model MohrCoulomb untuk tanah pasir homogen. Peningkatan daya dukung lateral suction pile dapat dilihat pada Tabel 3. Kapasitas daya dukung lateral suction pile diperoleh dari outputprogram PLAXIS 3D yang ditampilkan dalam bentuk grafik hubungan rasio antara panjang dan diameter suction pile terhadap daya dukung lateral yang terjadi dapat dilihat pada Gambar 4.

\section{Tabel 3. Rekapitulasi Daya Dukung Lateral Keruntuhan Mohr-Coulomb}

\begin{tabular}{ccccc}
\hline \multirow{2}{*}{$\begin{array}{c}\text { Diameter } \\
\text { [m] }\end{array}$} & Panjang & & $\boldsymbol{U}_{\boldsymbol{x}}$ & $\boldsymbol{Q}_{\boldsymbol{u}}$ \\
\cline { 1 - 3 } & {$[\mathbf{m}]$} & & {$[\mathbf{m}]$} & {$[\mathbf{k N}]$} \\
\hline 3 & 3 & $1: 1$ & 0,025 & 354,681 \\
\hline 3 & 6 & $1: 2$ & 0,025 & 605,557 \\
\hline 3 & 9 & $1: 3$ & 0,025 & 890,144 \\
\hline 3 & 12 & $1: 4$ & 0,025 & $1.141,291$ \\
\hline 3 & 15 & $1: 5$ & 0,025 & $1.387,907$ \\
\hline 3 & 18 & $1: 6$ & 0,025 & $1.615,292$ \\
\hline 3 & 21 & $1: 7$ & 0,025 & $1.809,198$ \\
\hline 3 & 24 & $1: 8$ & 0,025 & $1.952,989$ \\
\hline
\end{tabular}

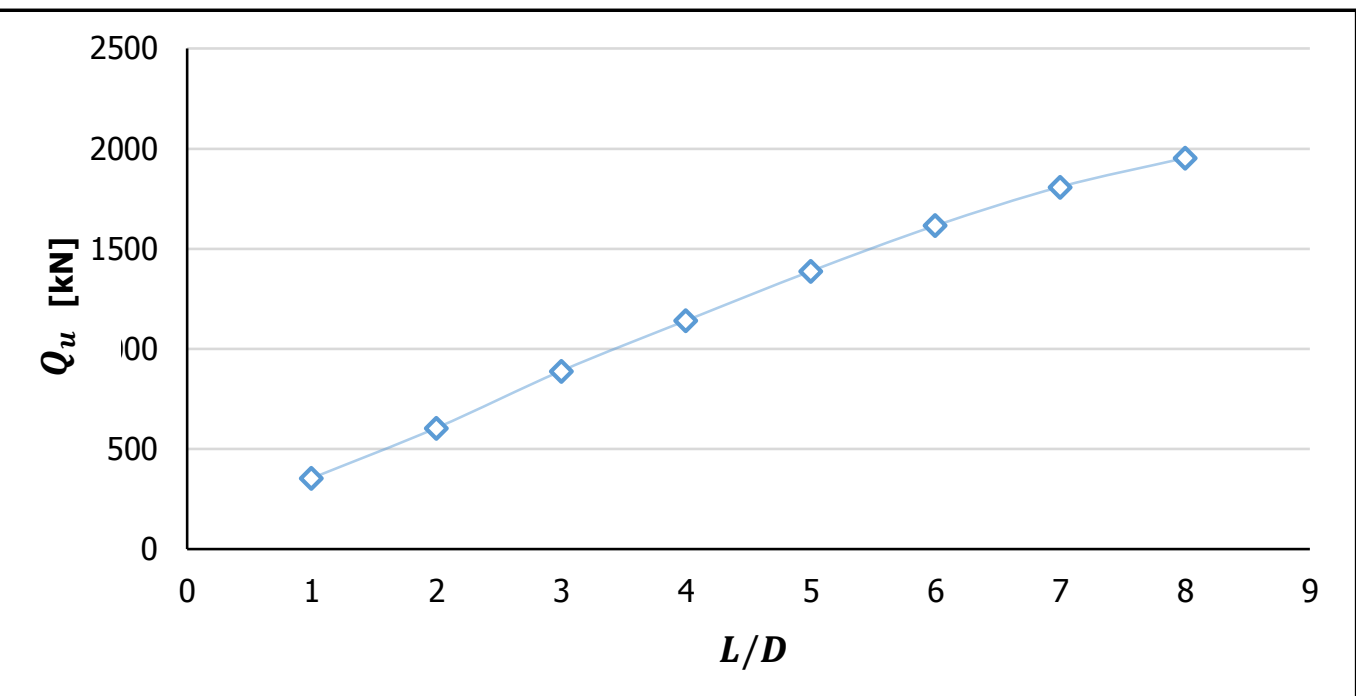

Gambar 4. Grafik hubungan rasio $L / D$ dengan daya dukung lateral keruntuhan MohrCoulomb

\section{B) Pemodelan dengan Model Hardening Soil}

Pemodelan yang dilakukan pertama kali adalah pemodelan dengan menggunakan model hardening soil untuk tanah pasir homogen. Peningkatan daya dukung lateral suction pile dapat dilihat pada Tabel 4. Kapasitas daya dukung lateral suction pile diperoleh dari output program PLAXIS 3D yang ditampilkan dalam bentuk grafik hubungan pengaruh rasio antara panjang dan diameter suction pile terhadap daya dukung lateral yang terjadi dapat dilihat pada Gambar 5. 
Tabel 4. Rekapitulasi Daya Dukung Lateral Keruntuhan Hardening Soil

\begin{tabular}{|c|c|c|c|c|}
\hline Diameter & Panjang & & $\boldsymbol{U}_{\boldsymbol{x}}$ & $Q_{u}$ \\
\hline [m] & [m] & & [m] & {$[\mathbf{k N}]$} \\
\hline 3 & 3 & $1: 1$ & 0,025 & 222,573 \\
\hline 3 & 6 & $1: 2$ & 0,025 & 376,982 \\
\hline 3 & 9 & $1: 3$ & 0,025 & 571,957 \\
\hline 3 & 12 & $1: 4$ & 0,025 & 765,367 \\
\hline 3 & 15 & $1: 5$ & 0,025 & 978,412 \\
\hline 3 & 18 & $1: 6$ & 0,025 & $1.176,824$ \\
\hline 3 & 21 & $1: 7$ & 0,025 & $1.318,234$ \\
\hline 3 & 24 & $1: 8$ & 0,025 & $1.476,677$ \\
\hline
\end{tabular}

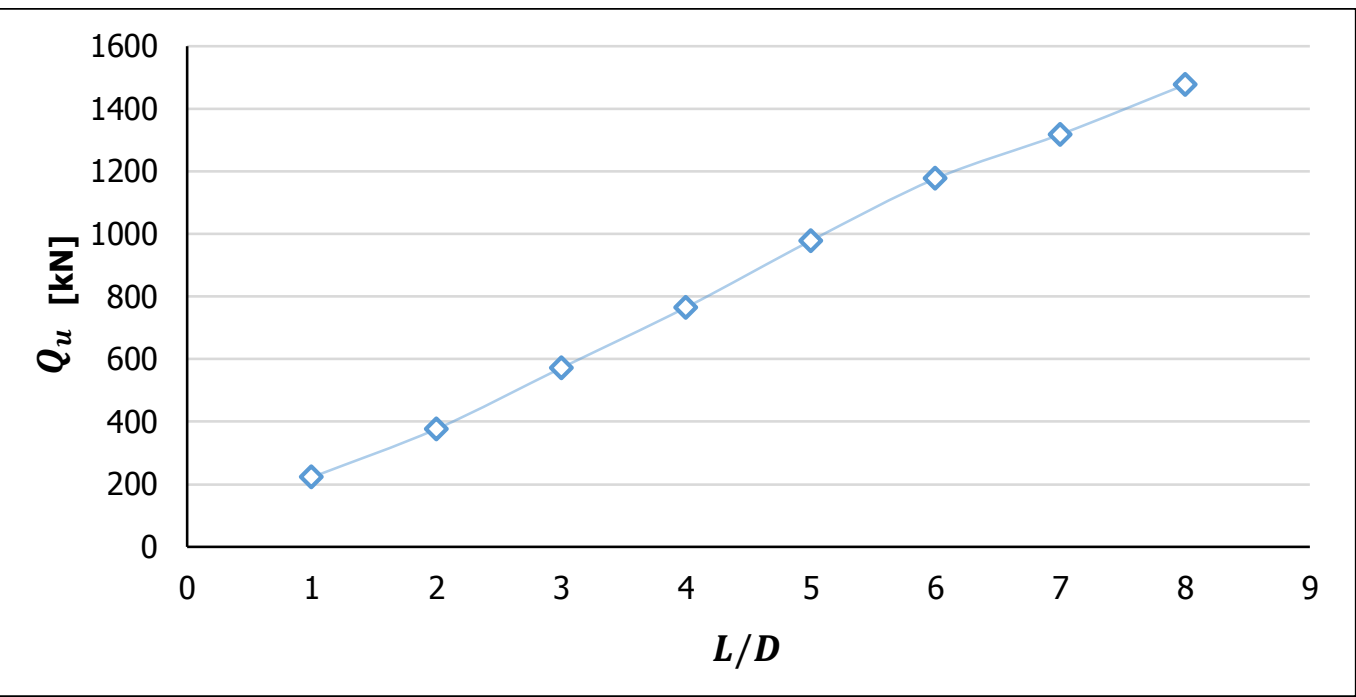

Gambar 5. Grafik hubungan rasio $L / D$ dengan daya dukung lateral keruntuhan Hardening Soil

Analisis daya dukung lateral pada suction pile menggunakan Metode Elemen Hingga dari program PLAXIS 3D ini menunjukkan bahwa dengan diameter suction pile tetap, semakin panjang kedalaman dari suction pile, maka daya dukung lateral yang diperoleh semakin besar. Peningkatan daya dukung lateral yang terjadi karena letak fixity point yang masih dekat dengan permukaan tanah dan dapat dikatakan letak fixity point pada suction pile masih bergerak turun ke bawah hingga menemukan letak fixity point yang tetap. Sehingga akibat letak fixity point yang masih turun ke bawah dan belum mencapai letak yang stabil maka, daya dukung lateral yang didapatkan akan semakin besar hingga mencapai panjang suction pile yang sesuai.

\subsection{Daya Dukung Lateral Metode Analisis}

Daya dukung lateral diperoleh dengan cara coba-coba besar beban lateral pada suction pile yang menghasilkan defleksi lateral yang sama besar nilainya dengan defleksi lateral izin, yaitu $2,5 \mathrm{~cm}$. Peningkatan daya dukung lateral suction pile dapat dilihat pada Tabel 5. 
Tabel 5. Rekapitulasi Daya Dukung Lateral dengan Metode COM624

\begin{tabular}{|c|c|c|c|c|}
\hline Diameter & Panjang & Dasio & $\boldsymbol{U}_{x}$ & $Q_{u}$ \\
\hline$[\mathrm{m}]$ & {$[\mathrm{m}]$} & & [m] & [kN] \\
\hline 3 & 3 & $1: 1$ & 0,025 & 60 \\
\hline 3 & 6 & $1: 2$ & 0,025 & 240 \\
\hline 3 & 9 & 1:3 & 0,025 & 540 \\
\hline 3 & 12 & $1: 4$ & 0,025 & 957 \\
\hline 3 & 15 & $1: 5$ & 0,025 & 1490 \\
\hline 3 & 18 & $1: 6$ & 0,025 & 1990 \\
\hline 3 & 21 & $1: 7$ & 0,025 & 2420 \\
\hline 3 & 24 & $1: 8$ & 0,025 & 2920 \\
\hline
\end{tabular}

Kapasitas daya dukung lateral suction pile diperoleh dari hasil analisis menggunakan metode COM624 yang ditampilkan dalam bentuk grafik hubungan rasio antara panjang dan diameter suction pile terhadap daya dukung lateral yang terjadi dapat dilihat pada Gambar 6.

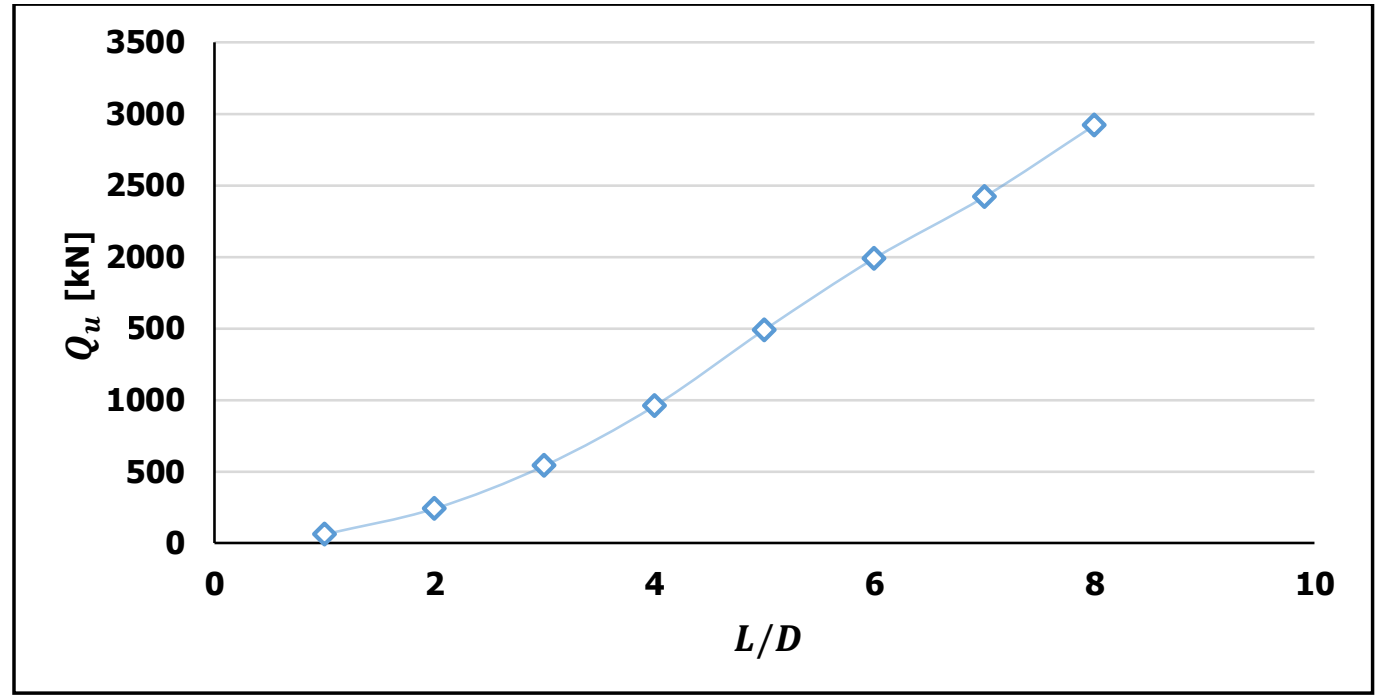

Gambar 6. Grafik hubungan rasio $L / D$ dengan daya dukung lateral metode Com624

\subsection{Perbandingan Metode Analisis Daya Dukung Lateral}

Hasil perbandingan analisis dari kedua soil mode/ ini menunjukan bahwa daya dukung lateral yang diperoleh berdasarkan defleksi lateral izin sebesar $2,5 \mathrm{~cm}$ pada soil model hardening soil lebih rendah dibandingkan dengan soil model Mohr-Coulomb seperti yang dapat dilihat pada Gambar 7. Daya dukung lateral pada soil mode/ Mohr-Coulomb yang diperoleh memiliki nilai rata-rata 31,48\% lebih besar dibandingkan Hardening Soil. Perbedaan daya dukung lateral dari hasil analisis kedua soil mode/yang dilakukan karena parameter yang digunakan pada soil model hardening soil memiliki 3 jenis $E$, sehingga menyebabkan daya dukung lateral pada soil model hardening soil lebih besar dibandingkan dengan soil mode/ Mohr Coulomb. 


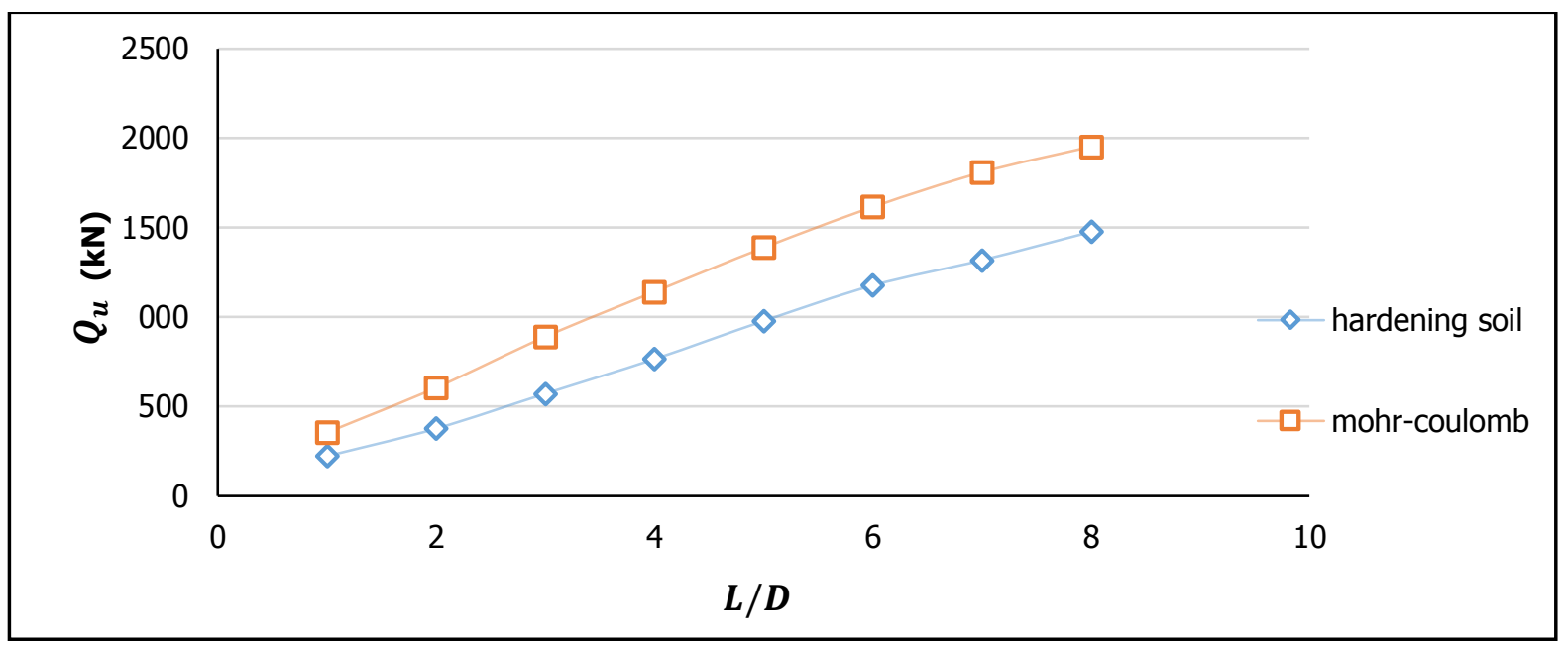

Gambar 7. Grafik perbandingan keruntuhan Mohr-Coulomb dan hardening soil

Hasil analisis daya dukung lateral menggunakan program PLAXIS 3D yang kemudian dibandingkan dengan metode COM624 dapat dilihat pada Tabel 6 dan perbandingan analisis daya dukung lateral terhadap rasio dari hasil analisis PLAXIS 3D baik menggunakan soil model Mohr-Coulomb dan Hardening Soil dan analisis menggunakan metode COM624 seperti pada Gambar 8.

Tabel 6. Rekapitulasi Daya Dukung Lateral pada Suction Pile

\begin{tabular}{ccccc}
\hline \multirow{2}{*}{ Rasio } & $\boldsymbol{U}_{\boldsymbol{x}}[\mathbf{m}]$ & Mohr-Coulomb & Hardening Soil & COM624 \\
\cline { 2 - 5 } & & $\boldsymbol{Q}_{\boldsymbol{u}}[\mathbf{k N}]$ & $\boldsymbol{Q}_{\boldsymbol{u}}[\mathbf{k N}]$ & $\boldsymbol{Q}_{\boldsymbol{u}}[\mathbf{k N}]$ \\
\hline $1: 1$ & 0,025 & 354,681 & 222,573 & 60 \\
\hline $1: 2$ & 0,025 & 605,557 & 376,982 & 240 \\
\hline $1: 3$ & 0,025 & 890,144 & 571,957 & 540 \\
\hline $1: 4$ & 0,025 & $1.141,291$ & 765,367 & 957 \\
\hline $1: 5$ & 0,025 & $1.387,907$ & 978,412 & 1.490 \\
\hline $1: 6$ & 0,025 & $1.615,292$ & $1.176,824$ & 1990 \\
\hline $1: 7$ & 0,025 & $1.809,198$ & $1.318,234$ & 2420 \\
\hline $1: 8$ & 0,025 & $1.952,989$ & $1.476,677$ & 2920 \\
\hline
\end{tabular}

Data di atas menunjukan bahwa perbandingan daya dukung lateral hasil analisis menggunakan PLAXIS 3D yang diperoleh jika dibandingkan dengan hasil analisis menggunakan metode COM624 berdasarkan defleksi lateral izin sebesar $2,5 \mathrm{~cm}$ memiliki nilai persentase selisih daya dukung lateral yang berbeda tiap pertambahan panjang suction pile. Daya dukung lateral pada metode COM624 yang diperoleh memiliki nilai rata-rata 39,10\% lebih besar dibandingkan Mohr-Coulomb sedangkan terhadap Hardening Soil, daya dukung lateral metode COM624 memiliki nilai rata-rata lebih besar $55,34 \%$. 


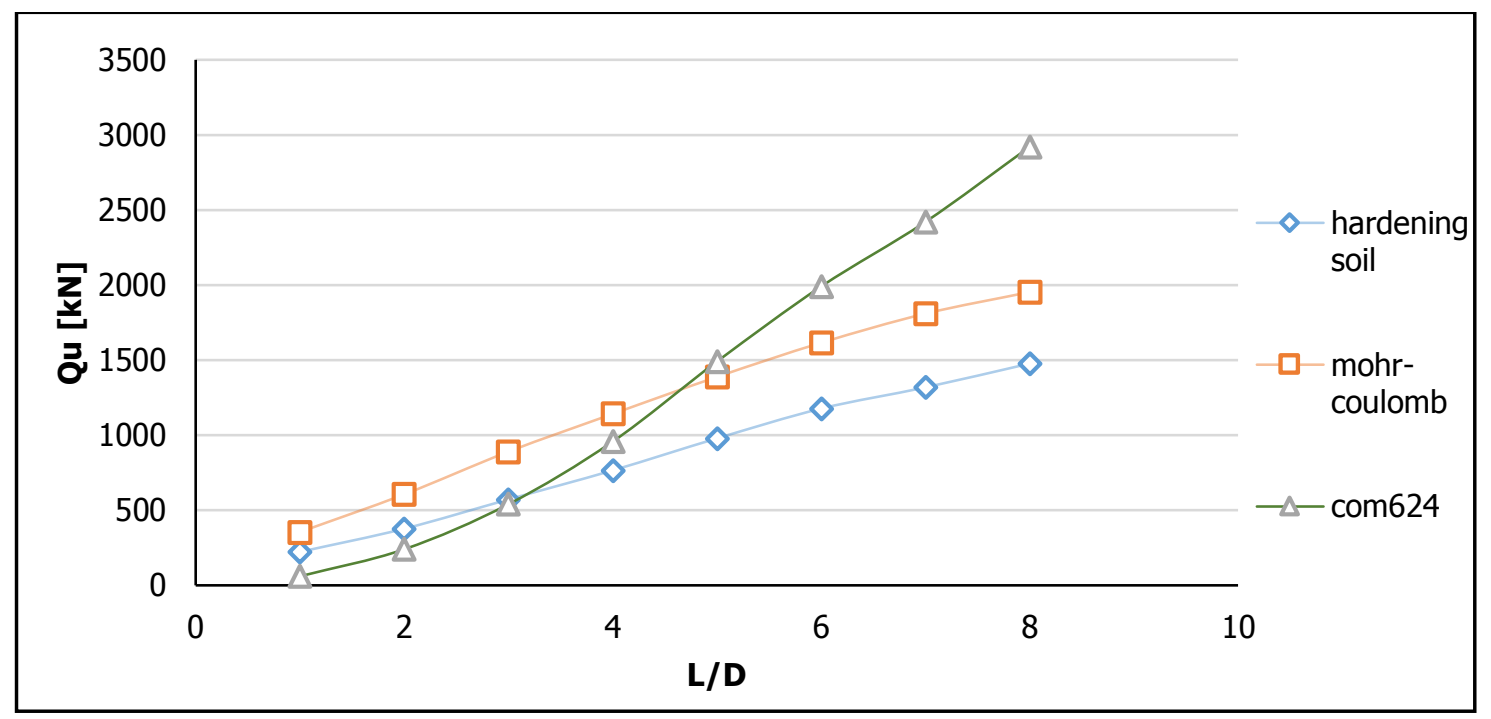

Gambar 8. Grafik perbandingan hasil analisis daya dukung lateral

Pada Gambar 8 terlihat perbandingan daya dukung lateral tiap metode yang digunakan untuk seluruh kenaikan rasio. Jika dilakukan perbandingan antara metode COM624 dan PLAXIS 3D dengan soil mode/Mohr-Coulomb dapat dilihat bahwa untuk rasio rentang 1:1 hingga 1:4 daya dukung lateral yang diperoleh dari metode COM624 masih berada di rentang yang sesuai dengan hasil analisis dari PLAXIS 3D, sedangkan pada rasio 1:5 dan 1:8 diperoleh daya dukung lateral yang lebih besar dibandingkan PLAXIS 3D. Kemudian jika dibandingkan antara metode COM624 dan PLAXIS 3D dengan soil model hardening soil dapat dilihat bahwa untuk rasio rentang 1:1 hingga 1:3 daya dukung yang diperoleh dari metode COM624 masih berada direntang yang sesuai dengan hasil analisis dari PLAXIS 3D, sedangkan pada rasio 1:4 hingga 1:8 diperoleh daya dukung lateral yang lebih besar dibandingkan PLAXIS. Hal ini disebabkan karena pada metode COM624 memiliki pendekatan yang berbeda yakni hanya memperhitungkan kekuatan dari suction pile dan modulus subgrade reaction soil $(k)$ tanpa memperhitungkan interface (bagian suction pile yang bergesekan dengan tanah), kontribusi tanah yang berada di dalam suction pile dan shear strength dari tanah itu sendiri.

Sehingga analisis daya dukung lateral suction pile saat menggunakan PLAXIS 3D dapat dikatakan lebih akurat dibandingkan analisis menggunakan metode COM624. Pada program PLAXIS 3D, analisis daya dukung lateral suction pile membuat pemodelan dengan memasukan parameter tanah pasir dan parameter suction pileyang akan digunakan. Analisis menggunakan PLAXIS 3D ini juga memperhitungkan kondisi dimana lapisan tanah tersebut jenuh karena dimodelkan muka air setinggi 1 meter diatas permukaan tanah, interface pada suction pile, dan tanah yang berada di dalam suction pile.

Perbedaan hasil analisis daya dukung lateral dari kedua metode tersebut memberikan variasi daya dukung lateral yang bergantung pada parameter-parameter yang digunakan dan diperhitungkan serta keterbatasan menganalisis fondasi dari kedua metode tersebut.

\section{KESIMPULAN}

Berdasarkan hasil penelitian yang telah dilakukan dapat ditarik simpulan sebagai berikut:

1. Semakin besar rasio antara panjang dan diameter penampang dari suction pile yang digunakan, maka daya dukung lateral yang diperoleh semakin meningkat dikarenakan letak fixity point yang masih turun ke bawah dan belum mencapai titik yang tetap. 
2. Daya dukung lateral yang diperoleh pada soil model Hardening Soillebih kecil dibandingkan dengan soil model Mohr-Coulomb. Perbedaan ini disebabkan karena parameter pada Hardening Soil terdapat 3 jenis $E$, yaitu $E_{50}, E_{o e d}$, dan $E_{u r}$.

3. Hasil analisis daya dukung lateral suction pile yang didapat menggunakan metode COM624 berbeda dengan hasil analisis menggunakan PLAXIS 3D dikarenakan adanya perbedaan pendekatan dari kedua metode yaitu parameter yang diperhitungkan dalam metode hanya kekuatan suction pile dan modulus subgrade reaction soiltanpa memperhitungkan interface pada suction pile, kontribusi tanah di dalam suction pile, dan shear strength tanah.

\section{DAFTAR RUJUKAN}

Allersma, H. G., Kirstein, A. A., Brinkgreve, R. B., \& Simon, T. (1999). Centrifuge and Numerical Modelling of Horizontally Loaded Suction Pile. International Offshore and Polar Engineering Conference (pp. 711 - 717). France: International Society of Offshore and Polar Engineers.

BSN. (2017). SNI 8460-2017 Persyaratan Perancangan Geoteknik. Jakarta: Badan Standarisasi Nasional.

FHWA. (1991). Design and Construction Guidelines Federal Highway Administration. Washington DC: Departement of Transportation.

Houlsby, G. T., \& Bryne, B. W. (2005). Design Procedures for Installation of Suction Caissons in Sand. Geotechnical Engineering, 158, 135-144.

Mohr, O. (1900). Welche umstande bedingen die elastizitatsgrenze und den bruch eines materiales? Zeitschrift des Vereines, 44, 1524-1530. 